\title{
Geologic Field Photograph Map of the Grand Canyon Region,
} 1967-2010

General Information Product 189

U.S. Department of the Interior U.S. Geological Survey 


\title{
U.S. Department of the Interior DAVID BERNHARDT, Secretary
}

\author{
U.S. Geological Survey \\ James F. Reilly II, Director
}

\section{U.S. Geological Survey, Reston, Virginia: 2019}

For more information on the USGS - the Federal source for science about the Earth, its natural and living resources, natural hazards, and the environment-visit https://www.usgs.gov or call 1-888-ASK-USGS.

For an overview of USGS information products, including maps, imagery, and publications, visit https://store.usgs.gov.

Any use of trade, firm, or product names is for descriptive purposes only and does not imply endorsement by the U.S. Government.

Although this information product, for the most part, is in the public domain, it also may contain copyrighted materials as noted in the text. Permission to reproduce copyrighted items must be secured from the copyright owner.

Suggested citation:

Billingsley, G.H., Goodwin, G., Nagorsen, S.E., Erdman, M.E., and Sherba, J.T., 2019, Geologic field photograph map of the Grand Canyon region, 1967-2010: U.S. Geological Survey General Information Product 189, 11 p., https://doi.org/10.3133/gip189.

ISSN 2332-354X (online)

Cover. Image EF69 of the photograph collection showing the view from the Tonto Trail (foreground) toward Indian Gardens (greenery), Bright Angel Fault, and Bright Angel Trail, which leads up to the south rim at Grand Canyon Village. Fault offset is down to the east (left) about 200 feet at the rim. 


\section{Foreword}

In 2019, Grand Canyon National Park celebrated the centennial of its founding. During the 100 years since, the Grand Canyon has enticed explorers, adventurers, scientists, and curious minds - drawn by its panoramic landscapes, dramatic geology, unique fauna and flora, and vital rivers. Mapping this wild and immense canyon is no simple task. One hundred and fifty years ago, John Wesley Powell began his pioneering expedition down the Colorado River through the entirety of the Grand Canyon. It was during this trip that Powell named it the Grand Canyon, an allusion to the grandeur of this geologic landmark. Though the expedition faced its share of hardship, including loss of scientific instruments and the departure of several crew members, its success is marked by the legacy of scientific endeavors in the canyon since 1869.

Powell himself led a second expedition in 1871-72, which retraced part of the first route and resulted in the first reliable maps of the Colorado River through the Grand Canyon, as well as extensive reports on the geography, geology, botany, and ethnography of the Colorado Plateau region. Additional surveys by geologist Clarence Dutton and coworkers of the newly formed U.S. Geological Survey — then under Director John Wesley Powell—were published as the first in-depth geologic report of the U.S. Geological Survey. This report, "Tertiary History of the Grand Cañon District, with Atlas," was published in 1882. The photographs, maps, and reports resulting from these early expeditions launched more than a century of research to uncover the geology of the Grand Canyon region.

One researcher who has contributed significantly to our understanding of Grand Canyon geology is George Billingsley, now geologist emeritus for the U.S. Geological Survey. Billingsley conducted geologic mapping in the Grand Canyon area from 1967 through 2010. The mapping project was supported by both the U.S. Geological Survey and the National Park Service, and Billingsley was able to access via helicopter places that were otherwise inaccessible. During his 43 years of mapping in and around the Grand Canyon, Billingsley captured thousands of photographs of the geology, the wildlife and vegetation, the environment, and the scenery. We are delighted to publish these unique photographs, all with brief explanations of the geology and scenery, and linked spatially to the topography.

Billingsley earned his Bachelor of Science (1968) and Master's (1970) degrees in geology from Northern Arizona University. He and coworkers published the nine 1:100,000-scale geologic maps that cover the Grand Canyon and surrounding area, which are included as a layer in the published web map application. Billingsley even named a new geologic formation in the Grand Canyon, the Surprise Canyon Formation, which he discovered in the early 1970 s.

The photographs published in this collection document the geology, mineral and water resources, landforms, and some history of the Grand Canyon as seen through the eyes of a keen geologic mapper and scientist.

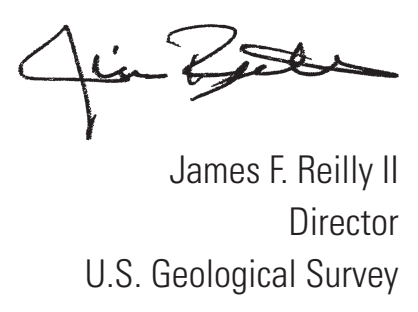




\section{Contents}

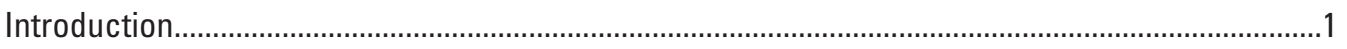

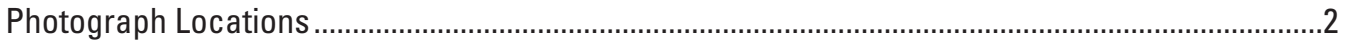

Photograph Topics and Categories...........................................................................................

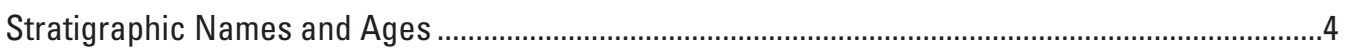

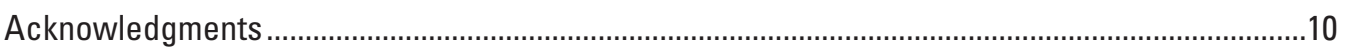

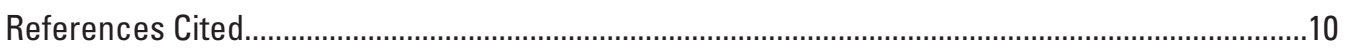

Geologic Maps of the Grand Canyon .......................................................................................11

\section{Figures}

1. Overview map of the Grand Canyon region, northern Arizona............................................2

2. Schematic column showing stratigraphic and structural relations of geologic formations in the Grand Canyon...................................................................................

3. Photograph ES154 showing Mesoproterozoic rocks of the Unkar Group in the eastern Grand Canyon. .....................................................................................................

4. Photograph ES143 showing Mesoproterozoic rocks and the overlying Neoproterozoic Nankoweap Formation and lower Tonto Group formations in the eastern Grand

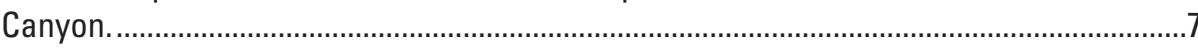

5. Photograph ES58 showing upper Tonto Group formations, Temple Butte Formation, and the Paleozoic Redwall Limestone in the eastern Grand Canyon...............................8

6. Photograph ES41 showing the Paleozoic Supai Group and the underlying Surprise Canyon Formation and Redwall Limestone in the eastern Grand Canyon.........................8

7. Photograph ES66 showing the Paleozoic Kaibab Formation, Toroweap Formation, Coconino Sandstone, Hermit Formation, and upper Supai Group formations in the eastern Grand Canyon.

8. Photograph ES05 showing Mesozoic rocks in the eastern Grand Canyon. ....................10

\section{Tables}

1. Labeling system and counts by category for the 1,211 photographs in the Grand Canyon geologic field photograph web map application.

2. Names and ages of geologic formations and member units discussed in photograph captions. 


\title{
Geologic Field Photograph Map of the Grand Canyon Region, 1967-2010
}

\author{
By George H. Billingsley', Gregory Goodwin², Sarah E. Nagorsen'1, Monica E. Erdman', and Jason T. Sherba ${ }^{1}$
}

\begin{abstract}
Introduction
The Grand Canyon geologic field photograph collection contains 1,211 geotagged photographs collected during 43 years of geologic mapping from 1967 to 2010. The photographs document some key geologic features, structures, and rock unit relations that were used to compile nine geologic maps of the Grand Canyon region published at 1:100,000 scale, and many more maps published at 1:24,000 scale. Metadata for each photograph include description, date captured, coordinates, and a keyword system that places each photograph in one or more of the following categories: arches and windows, breccia pipes and collapse structures, faults and folds, igneous rocks, landslides and rockfalls, metamorphic rocks, sedimentary rocks, sinkholes, and springs and waterfalls. Original photograph slides are available at the Northern Arizona University Cline Library Special Collections and Archives.

The Geologic Field Photograph Map of the Grand Canyon Region, 1967-2010, is an interactive online map application that shows clusters of photograph thumbnails and popup windows that scale as users pan, zoom, and click around the map. The photographs can be filtered by category, searched based on date range, description, and keywords, and (or) downloaded. All information populated within the map is served from a ScienceBase record of the Grand Canyon field photograph collection (Billingsley and others, 2019) that can be accessed at https://doi.org/10.5066/F7WS8SHW.
\end{abstract}




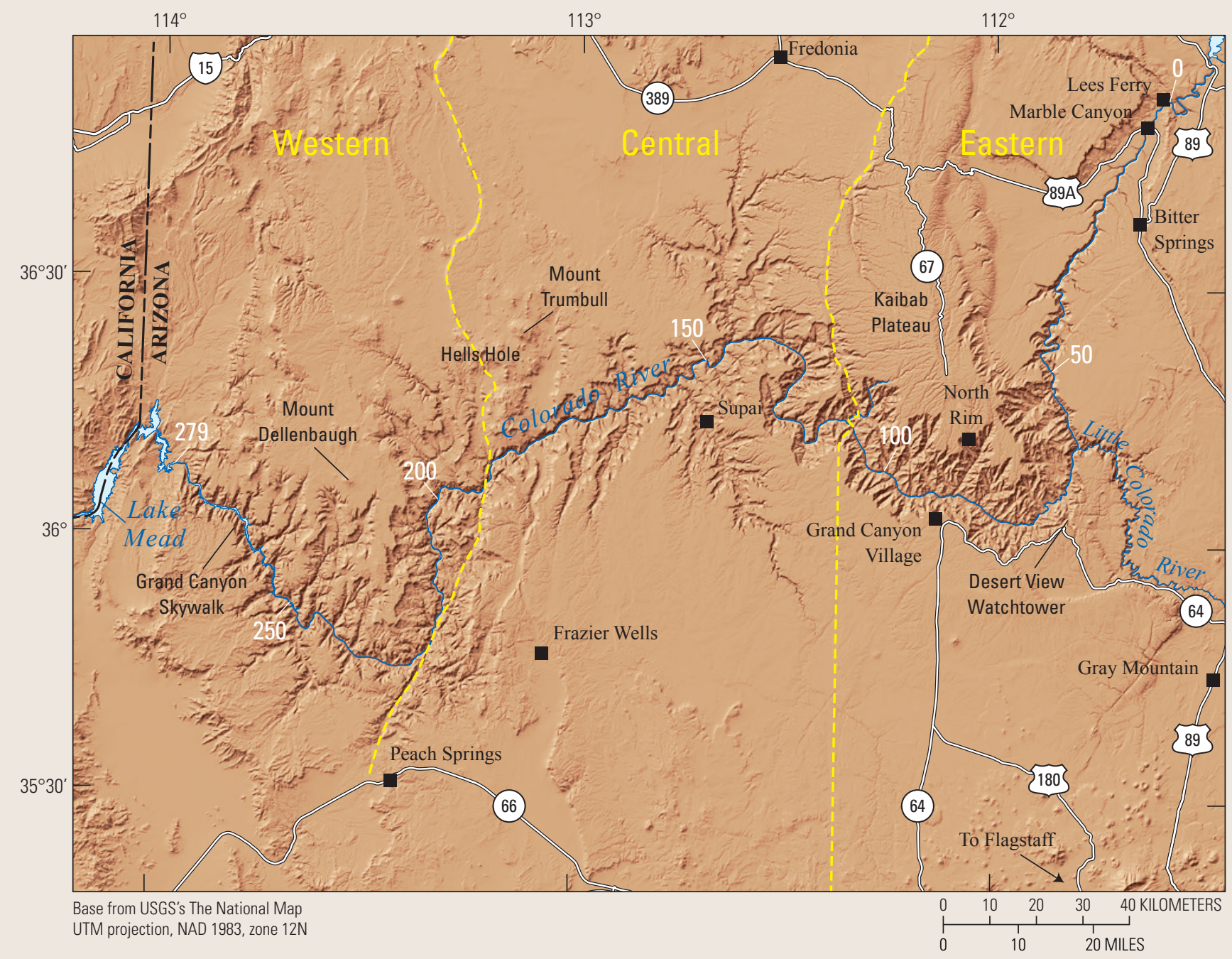

Figure 1. Overview map of the Grand Canyon region, northern Arizona, showing the western, central, and eastern Grand Canyon boundaries as used in the photograph collection.

\section{Photograph Locations}

The Colorado River has been surveyed and mapped by miles through the Grand Canyon starting at river mile 0 at Lees Ferry. Mileage increases downstream from Lees Ferry to the Grand Wash Cliffs at the mouth of Grand Canyon (river mile 277.0). Colorado River miles are those of the U.S. Geological Survey (2002). The Colorado River miles are commonly referred to in the photograph descriptions and are used as reference location points for many of the photographs. Photographs a few miles or more from the Colorado River are arbitrarily numbered to approximate location near the Colorado River. For photograph location purposes, the Grand Canyon region is subdivided into three parts - the eastern, central, and western Grand Canyon areas (fig. 1). The eastern Grand Canyon area begins at Colorado River mile 0.0 at Lees Ferry, Arizona, and continues down the Colorado River to river mile 108.0 at the Bass Trail. The central Grand Canyon area extends downriver from river mile 108.0 to river mile 191.0 at the Hurricane Fault. The western Grand Canyon area extends downriver from river mile 191.0 to river mile 277.0 at the Grand Wash Cliffs.

The eastern, central, and western Grand Canyon boundaries, north and south of the Colorado River (river miles 108.0 and 191.0), coincide with geologic structural boundaries for the most part (Billingsley and others,
1997). Thus, from Colorado River mile 108 northward, the boundary between eastern and central Grand Canyon is along Shinumo Creek to the Muav Fault, then northward along the Muav Fault north of the canyon rim to the ArizonaUtah State line. South of Colorado River mile 108 , the boundary between eastern and central Grand Canyon traverses southward up the Bass Trail in Bass Canyon to the south rim of the Grand Canyon. Southward from the south rim, a north-south line is drawn across the Coconino Plateau for several miles as an arbitrary boundary. From Colorado River mile 191, north and south of the river, the boundary between the central and western Grand Canyon is along the Hurricane Fault that marks a structural and physiographic natural boundary. 


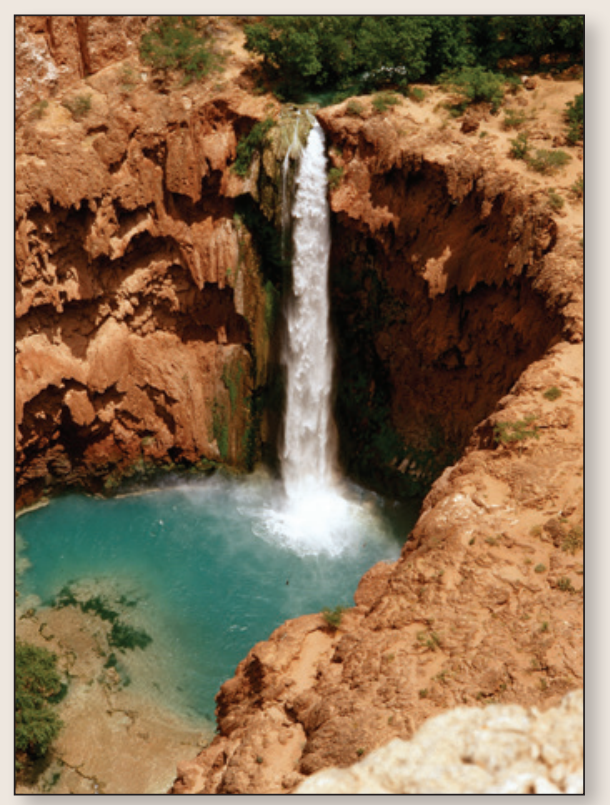

\section{Photograph Topics and Calegories}

The Grand Canyon is a region of horizontal to gently folded and faulted Phanerozoic strata that overlie a complex assemblage of igneous, metamorphic, and sedimentary Precambrian rocks. The Phanerozoic strata consist mostly of siltstone, sandstone, conglomerate, limestone, and dolomite ranging in age from Early Cambrian to Early Triassic in the walls of the Grand Canyon and on the surrounding plateau surfaces.

The physiography of the Grand Canyon is approximately 2,600 square miles in area, as determined by Billingsley and Hampton (1999). Mesozoic sedimentary rocks once covered the Grand Canyon area but are now limited to a few isolated outcrops near the rims of the Grand Canyon. Paleozoic sedimentary rocks make up the most visible rock formations throughout the Grand Canyon. Proterozoic sedimentary and igneous rocks are limited to a few isolated locations in the eastern and central Grand Canyon depths. Proterozoic crystalline rocks are limited to exposures along the Colorado River and in some tributaries, mainly in the eastern and western Grand Canyon areas.

Photograph categories include arches and windows, breccia pipes and

Table 1. Labeling system and counts by category for the 1,211 photographs in the Grand Canyon geologic field photograph web map application.

\begin{tabular}{lccc}
\hline \multicolumn{1}{c}{ Category } & $\begin{array}{c}\text { Eastern Grand } \\
\text { Canyon photograph } \\
\text { label; count }\end{array}$ & $\begin{array}{c}\text { Central Grand } \\
\text { Canyon photograph } \\
\text { label; count }\end{array}$ & $\begin{array}{c}\text { Western Grand } \\
\text { Canyon photograph } \\
\text { label; count }\end{array}$ \\
\hline $\begin{array}{l}\text { Arches and windows } \\
\text { Breccia pipes and } \\
\text { collapse structures }\end{array}$ & EA; 13 & CA; 16 & WA; 12 \\
Faults and folds & EB; 27 & CB; 35 & WB; 39 \\
Igneous rocks & EF; 82 & CF; 26 & WF; 48 \\
Landslides and rockfalls & EI; 15 & CI; 90 & WI; 52 \\
Metamorphic rocks & EL; 39 & CL; 29 & WL; 22 \\
Sedimentary rocks & EM; 37 & CM; 14 & WM; 32 \\
Sinkholes & ES; 183 & CS; 77 & WS; 82 \\
Springs and waterfalls & EH; 8 & CH; 6 & WH; 13 \\
\hline Total photographs & EW; 62 & CW; 113 & WW; 39 \\
\hline
\end{tabular}

collapse structures, faults and folds, igneous rocks, landslides and rockfalls, metamorphic rocks, sedimentary rocks, sinkholes, and springs and waterfalls (table 1). Arches form in rocks as they weather and erode; windows refer to the open space beneath arches. Collapse structures result from cave collapses throughout geologic time; the overlying column of broken rock resulting from the cave collapse forms a breccia pipe. Photographs of igneous, metamorphic, and sedimentary rocks and faults and folds highlight both small- and largescale features of varying ages in each category. Landslides and rockfalls result from the continuous interplay of erosion and steep canyon walls. Though springs and waterfalls are not necessarily rock features, water is the most valuable natural resource in the Grand Canyonarguably more so than all the mineral resources (such as copper or uranium) mined in the canyon. Where photographs fit into multiple categories, they are duplicated with different captions to explain the visible features. The photographs shown are not always of good quality owing to a lack of time for camera settings, limited amount of film, weather conditions, and (or) window clarity of the helicopter or airplane (in aerial photographs). Type of film used is 35-millimeter Kodachrome II color slide film.
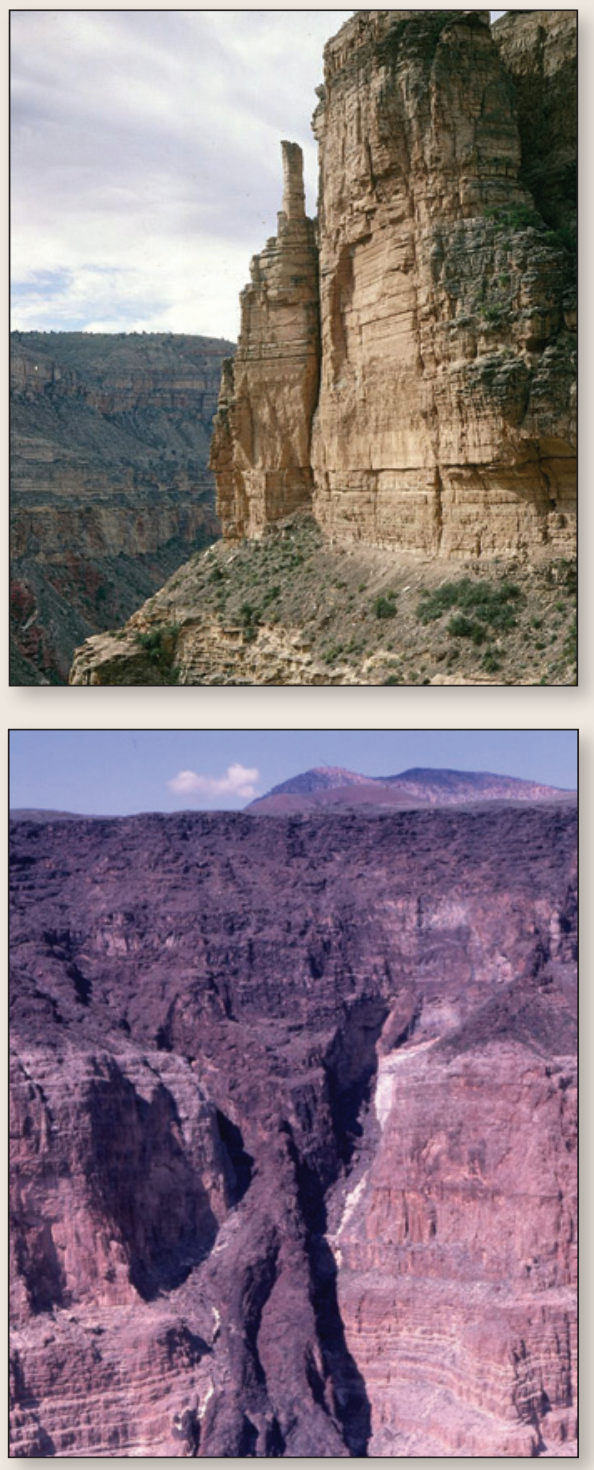


\section{Stratigraphic Names and Ages}

Geologic formation names are given in each photograph description when possible. For brevity, stratigraphic ages are included here with formation names rather than in photograph descriptions (table 2). Formal names are capitalized whereas informal names are lowercase. Stratigraphic ages reflect data from 2010; ages may change as new information is discovered. Figure 2 shows a schematic column of geologic formations and their relative positions as they might appear in the Grand Canyon region. Figures 3-8 outline many of the geologic formations in select annotated photographs from the collection.

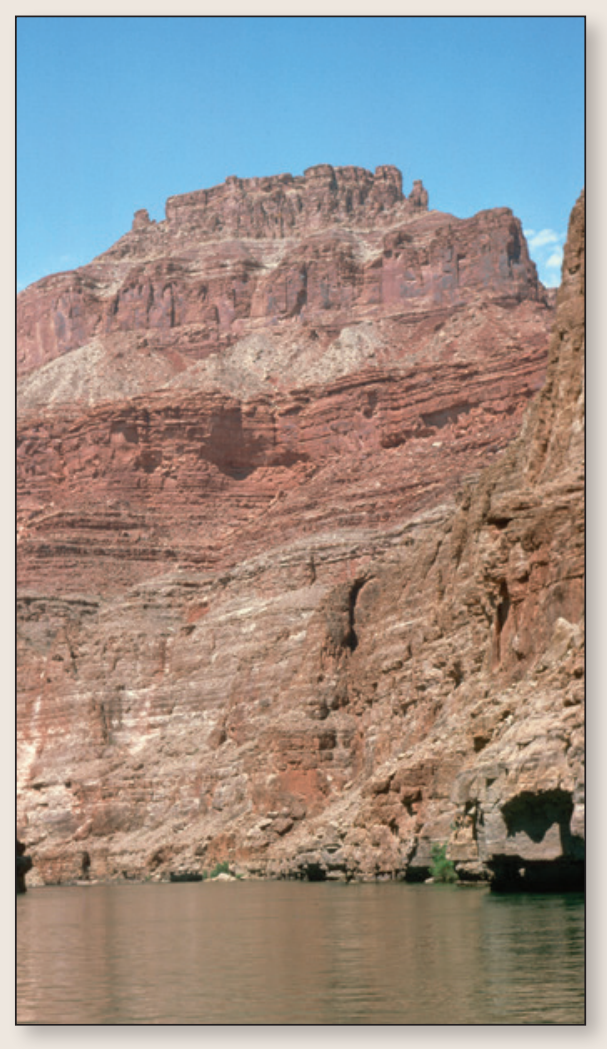

Table 2. Names and ages (as of 2010) of geologic formations and member units discussed in photograph captions.

[Symbols in parentheses are geologic age symbols]

\begin{tabular}{|c|c|c|c|}
\hline Era & Period/Subperiod & Formation & Member Unit \\
\hline \multirow{11}{*}{ 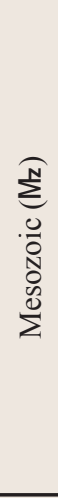 } & \multirow[t]{4}{*}{ Jurassic (J) } & Navajo Sandstone & \\
\hline & & Kayenta Formation & Springdale Sandstone Member \\
\hline & & Moenave Formation & \\
\hline & & Wingate Sandstone & \\
\hline & \multirow[t]{7}{*}{ Triassic $(\mathrm{k})$} & Chinle Formation & Owl Rock Member \\
\hline & & & Petrified Forest Member \\
\hline & & & \\
\hline & & Moenkopi Formation & upper red member \\
\hline & & & Shnabkaib Member \\
\hline & & & lower red member \\
\hline & & & Timpoweap Member \\
\hline \multirow{26}{*}{$\begin{array}{l}\widehat{N} \\
0 \\
0 \\
0 \\
0 \\
\frac{0}{\pi} \\
0\end{array}$} & \multirow[t]{9}{*}{ Permian $(P)$} & Kaibab Formation & Harrisburg Member \\
\hline & & & Fossil Mountain Member \\
\hline & & Toroweap Formation & Woods Ranch Member \\
\hline & & & Brady Canyon Member \\
\hline & & & Seligman Member \\
\hline & & Coconino Sandstone & \\
\hline & & Hermit Formation & \\
\hline & & Esplanade Sandstone & \\
\hline & & Pakoon Limestone & \\
\hline & \multirow[t]{3}{*}{ Pennsylvanian (P) } & Wescogame Formation & \\
\hline & & Manakacha Formation & \\
\hline & & Watahomigi Formation & \\
\hline & \multirow[t]{5}{*}{ Mississippian (M) } & Surprise Canyon Formation & \\
\hline & & Redwall Limestone & Horseshoe Mesa Member \\
\hline & & & Mooney Falls Member \\
\hline & & & Thunder Springs Member \\
\hline & & & Whitmore Wash Member \\
\hline & Devonian (D) & Temple Butte Formation & \\
\hline & \multirow[t]{8}{*}{ Cambrian $(€)$} & Undifferentiated dolomites & \\
\hline & & Muav Limestone & Havasu Member \\
\hline & & & Gateway Canyon Member \\
\hline & & & Kanab Canyon Member \\
\hline & & & Peach Springs Canyon Member \\
\hline & & & Rampart Cave Member \\
\hline & & Bright Angel Shale & $\begin{array}{l}\text { Flour Sack Member } \\
\text { red-brown member }\end{array}$ \\
\hline & & Tapeats Sandstone & \\
\hline
\end{tabular}

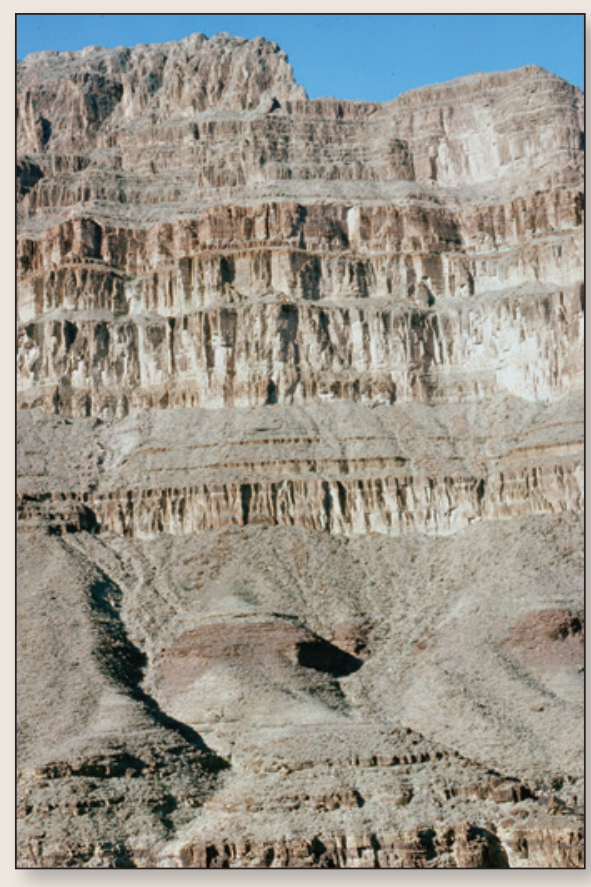




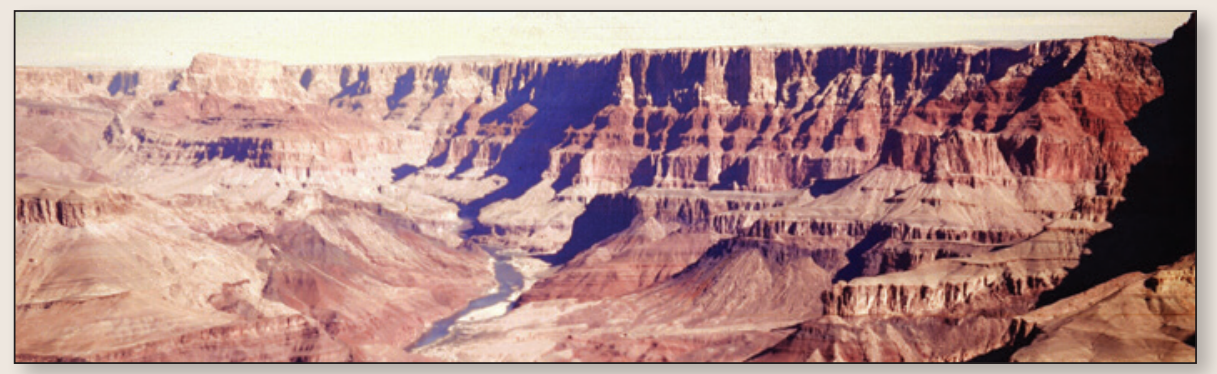

Table 2. Names and ages (as of 2010) of geologic formations and member units discussed in photograph captions. - Continued

\begin{tabular}{|c|c|c|c|}
\hline Era & Period/Subperiod & Formation & Member Unit \\
\hline \multirow{4}{*}{ 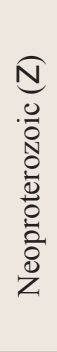 } & & Sixtymile Formation & \\
\hline & & Kwagunt Formation & $\begin{array}{l}\text { Walcott Member } \\
\text { Awatubi Member } \\
\text { Carbon Butte Member }\end{array}$ \\
\hline & & Galeros Formation & $\begin{array}{l}\text { Carbon Canyon Member } \\
\text { Jupiter Member } \\
\text { Tanner Member }\end{array}$ \\
\hline & & Nankoweap Formation & \\
\hline \multirow{5}{*}{ 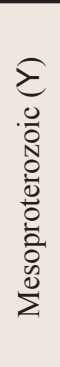 } & \multirow{5}{*}{ 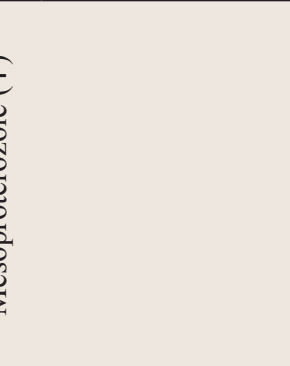 } & \multicolumn{2}{|l|}{ Cardenas Basalt } \\
\hline & & Dox Formation & $\begin{array}{l}\text { Ochoa Point Member } \\
\text { Comanche Point Member } \\
\text { Solomon Temple Member } \\
\text { Escalante Creek Member }\end{array}$ \\
\hline & & Shinumo Sandstone & \\
\hline & & Hakatai Shale & \\
\hline & & Bass Formation & Hotauta Conglomerate Member \\
\hline \multirow{2}{*}{ 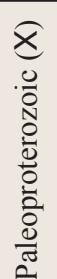 } & & Zoroaster Granite & \\
\hline & & Vishnu Schist & \\
\hline
\end{tabular}
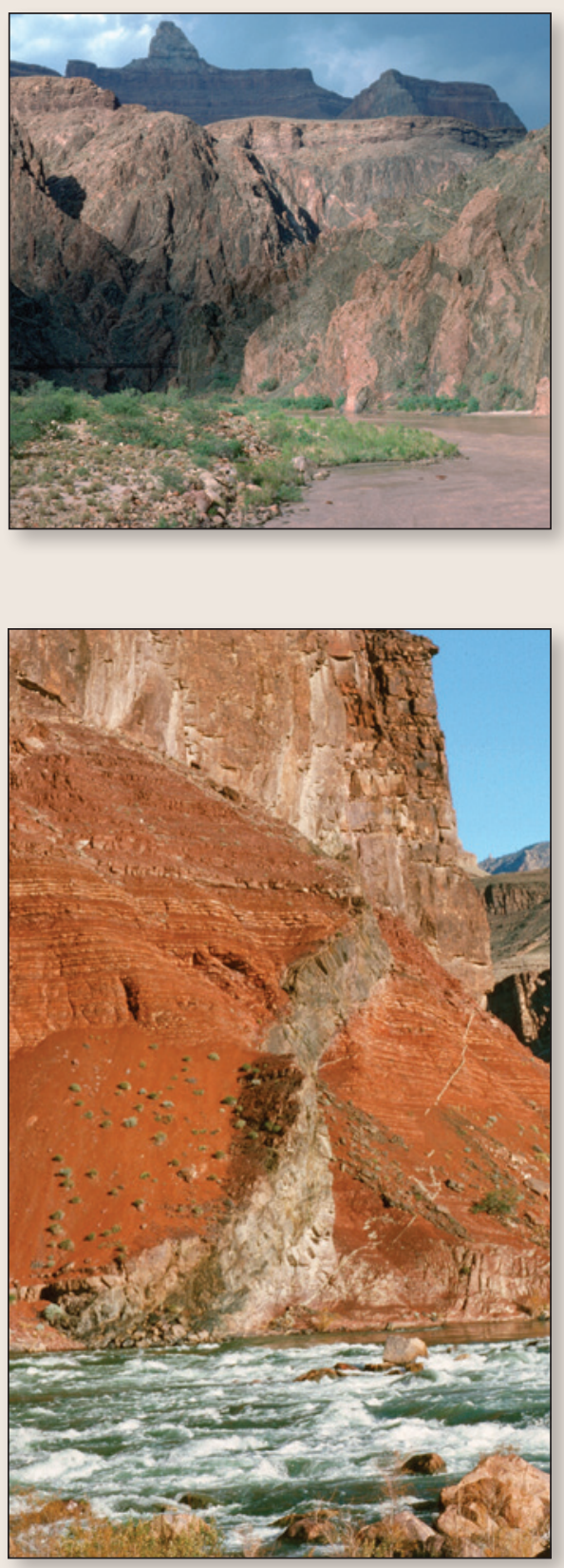
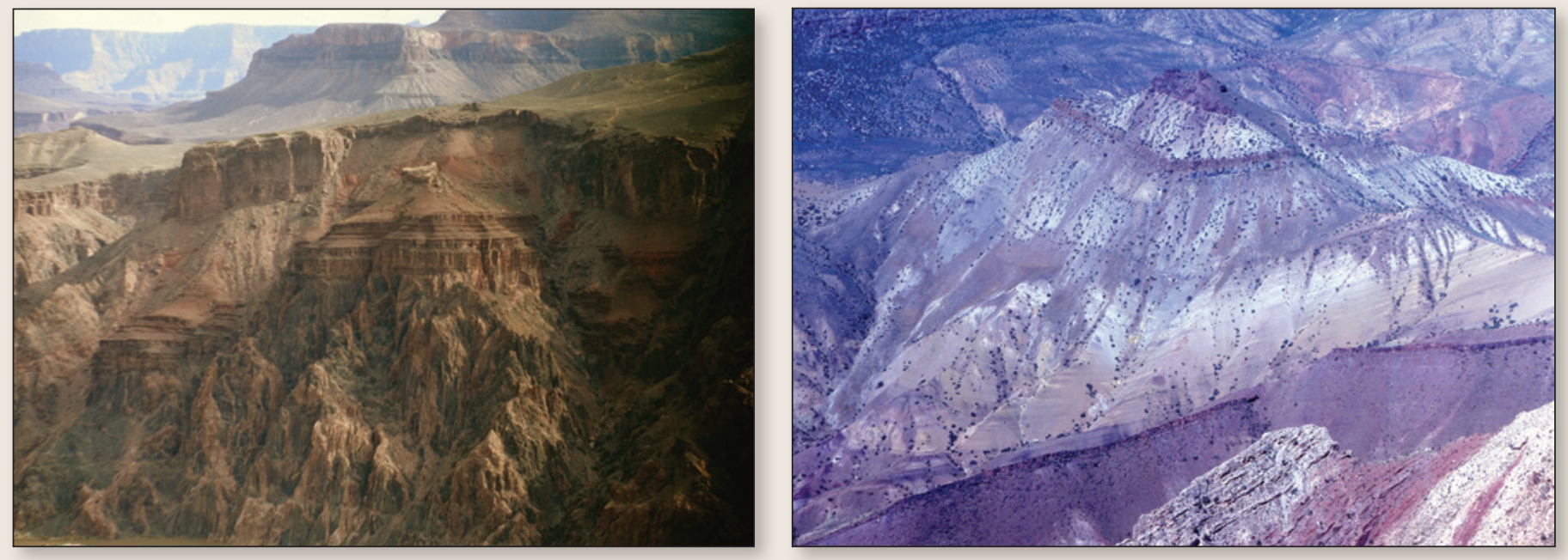


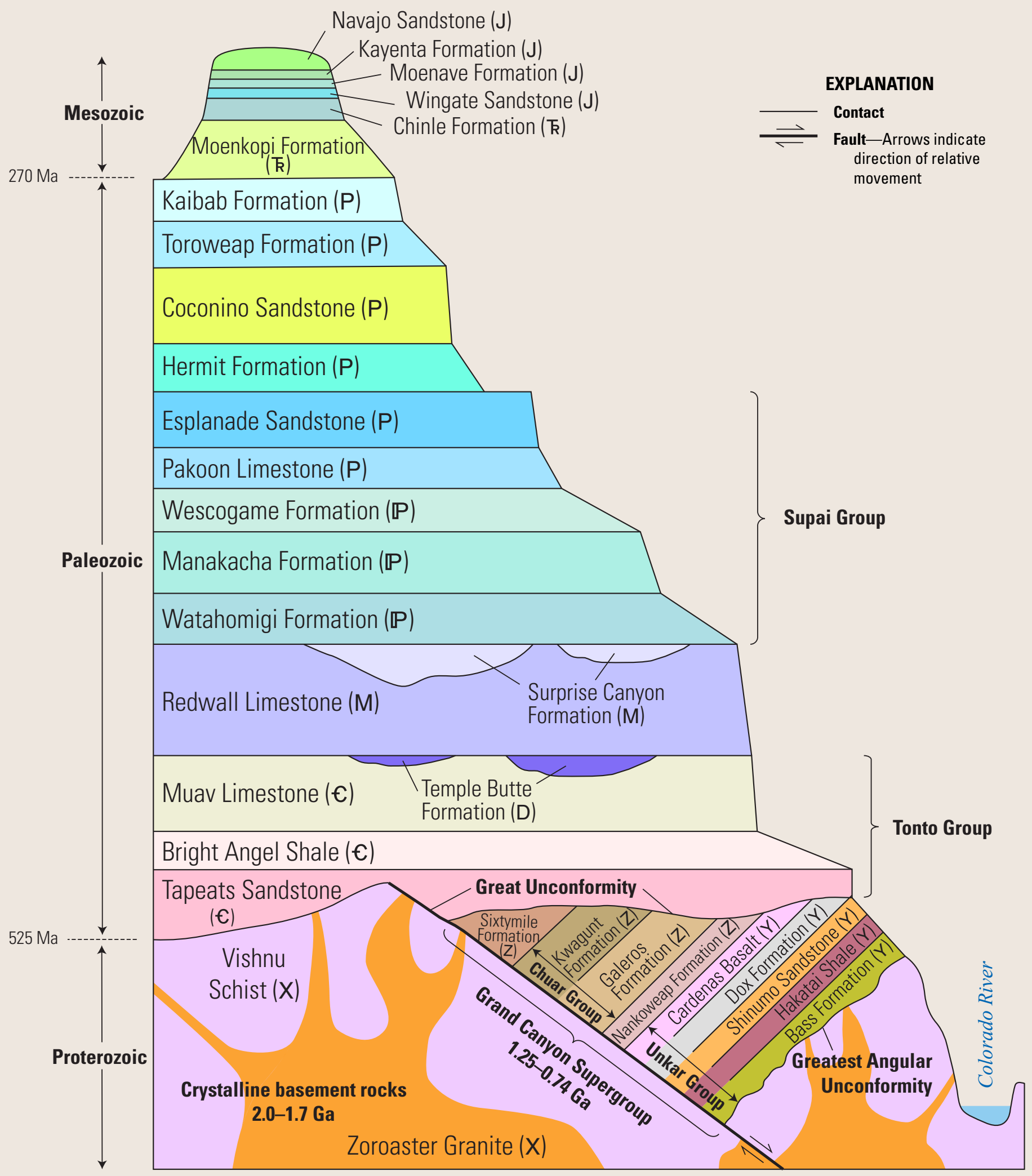

Figure 2. Schematic column showing stratigraphic and structural relations of geologic formations in the Grand Canyon. Symbols in parentheses provide the age (as of 2010) of the rock formation: J, Jurassic; $K$, Triassic; P, Permian; $\mathbb{P}$, Pennsylvanian; $M$, Mississippian; D, Devonian; $€$, Cambrian; Z, Neoproterozoic; Y, Mesoproterozoic; X, Paleoproterozoic. Numeric ages are given in millions of years ago (Ma) and billions of years ago (Ga). Colors correspond to the geologic map layer in the web map application. 


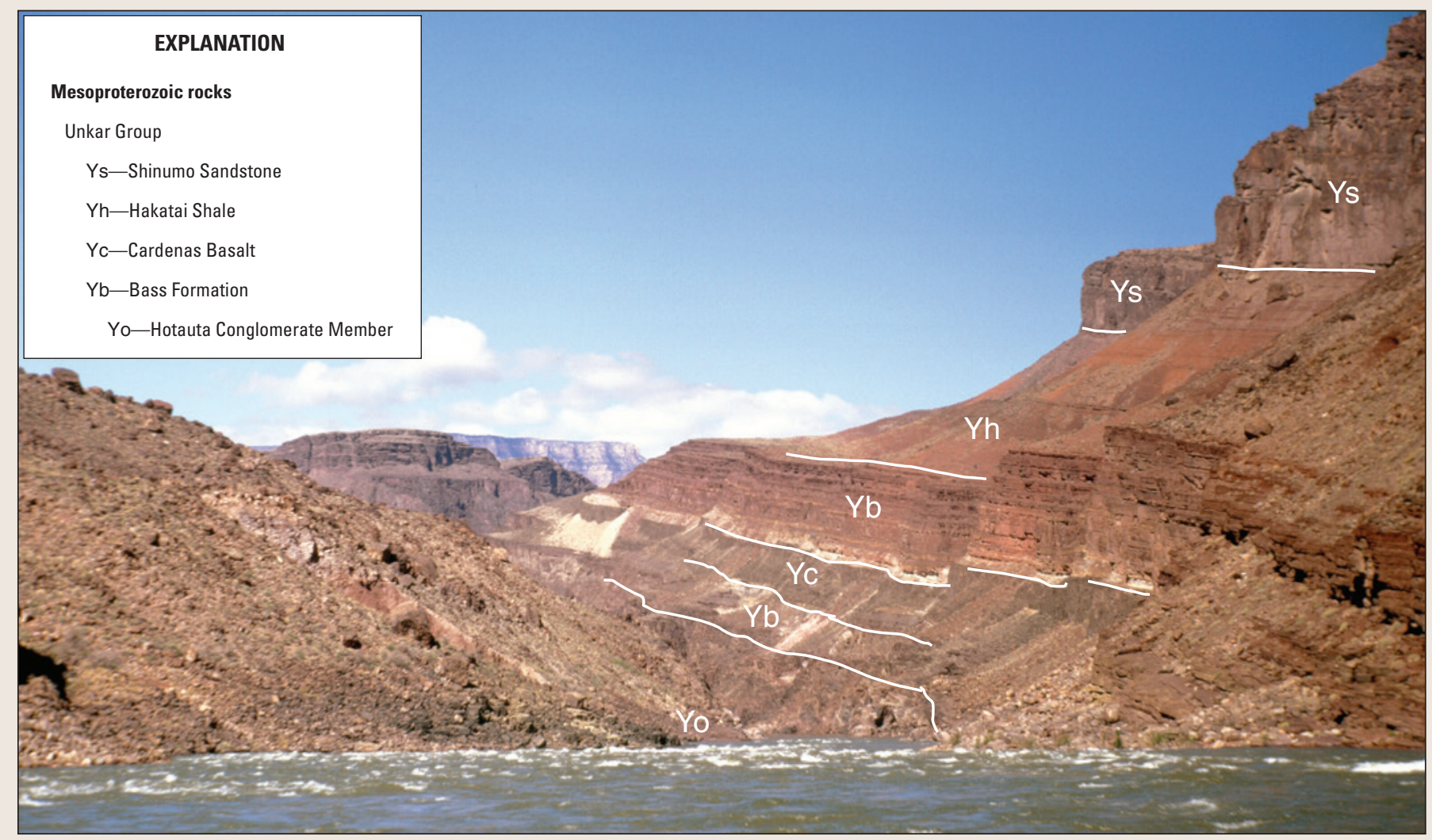

Figure 3. Photograph ES154 showing Mesoproterozoic rocks of the Unkar Group in the eastern Grand Canyon.

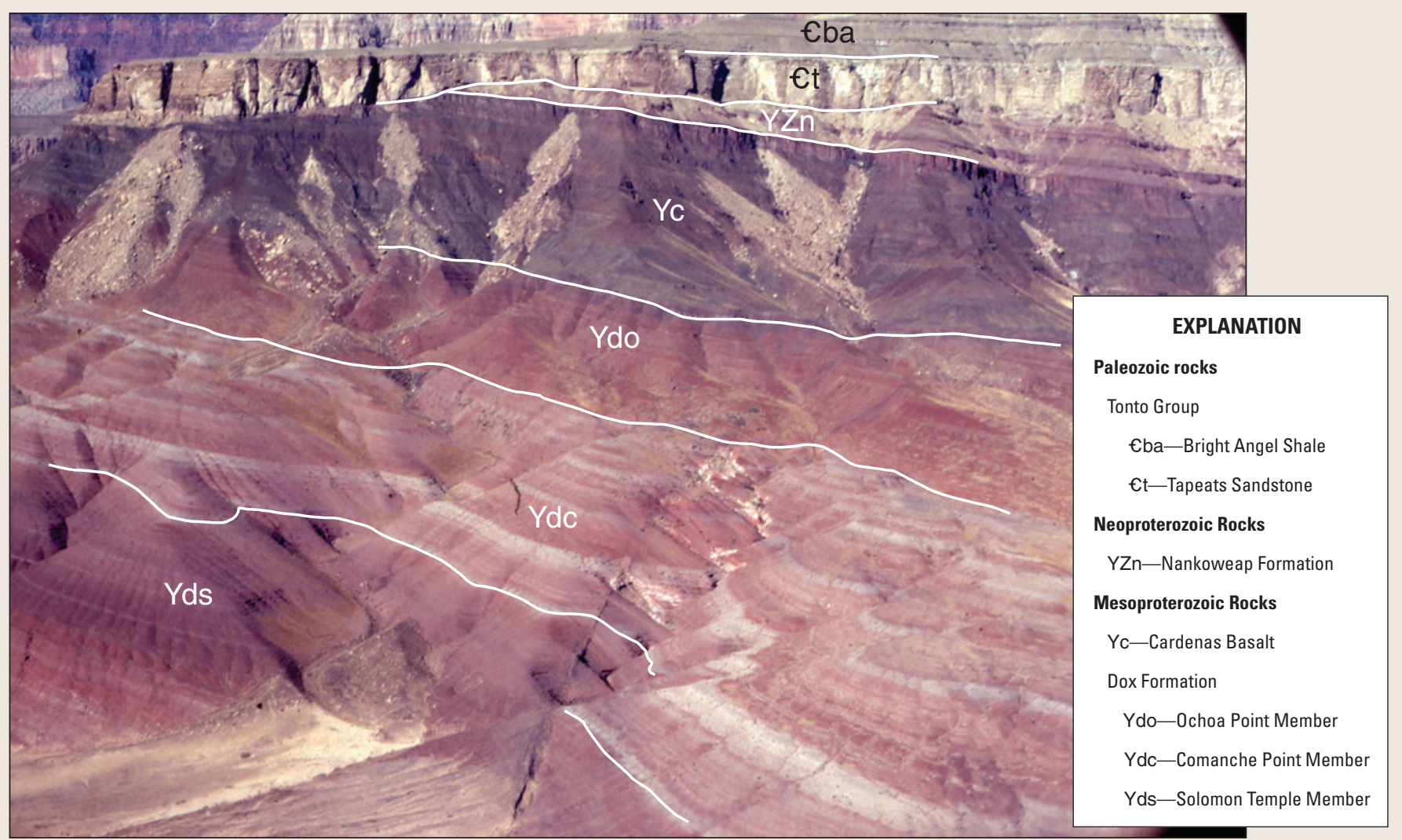

Figure 4. Photograph ES143 showing Mesoproterozoic rocks and the overlying Neoproterozoic Nankoweap Formation and lower Tonto Group formations in the eastern Grand Canyon. 


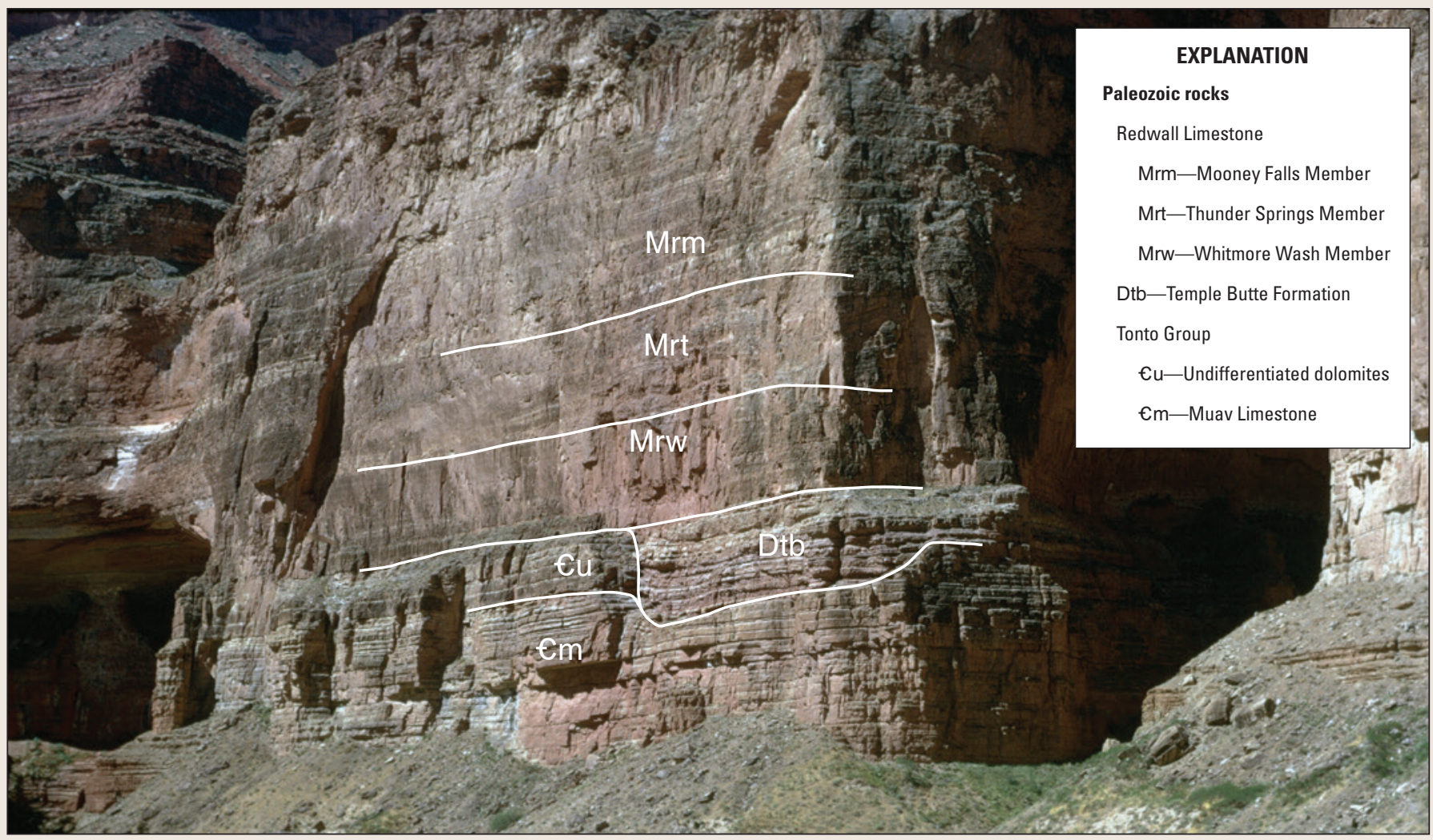

Figure 5. Photograph ES58 showing upper Tonto Group formations, Temple Butte Formation, and the Paleozoic Redwall Limestone in the eastern Grand Canyon.

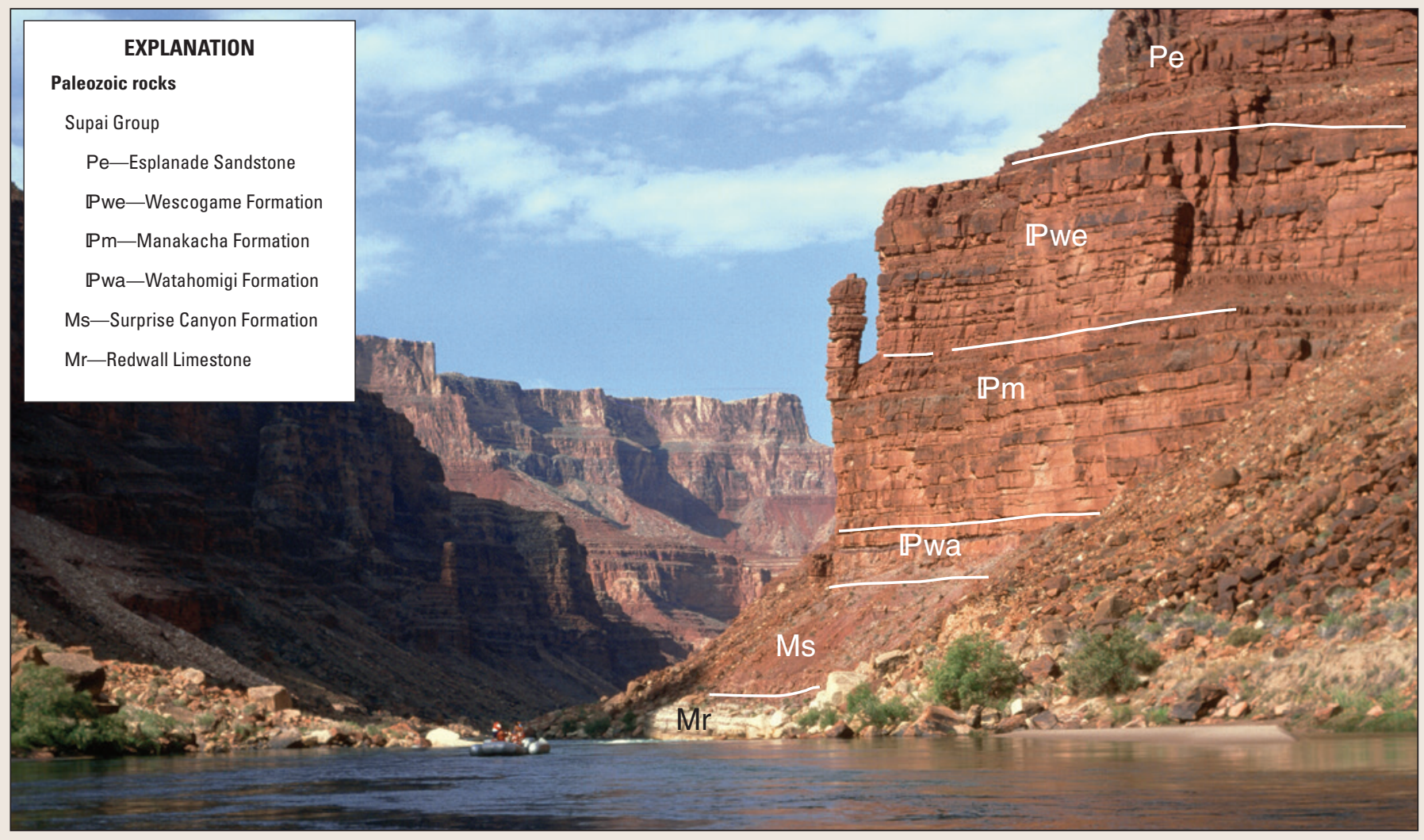

Figure 6. Photograph ES41 showing the Paleozoic Supai Group and the underlying Surprise Canyon Formation and Redwall Limestone in the eastern Grand Canyon. 


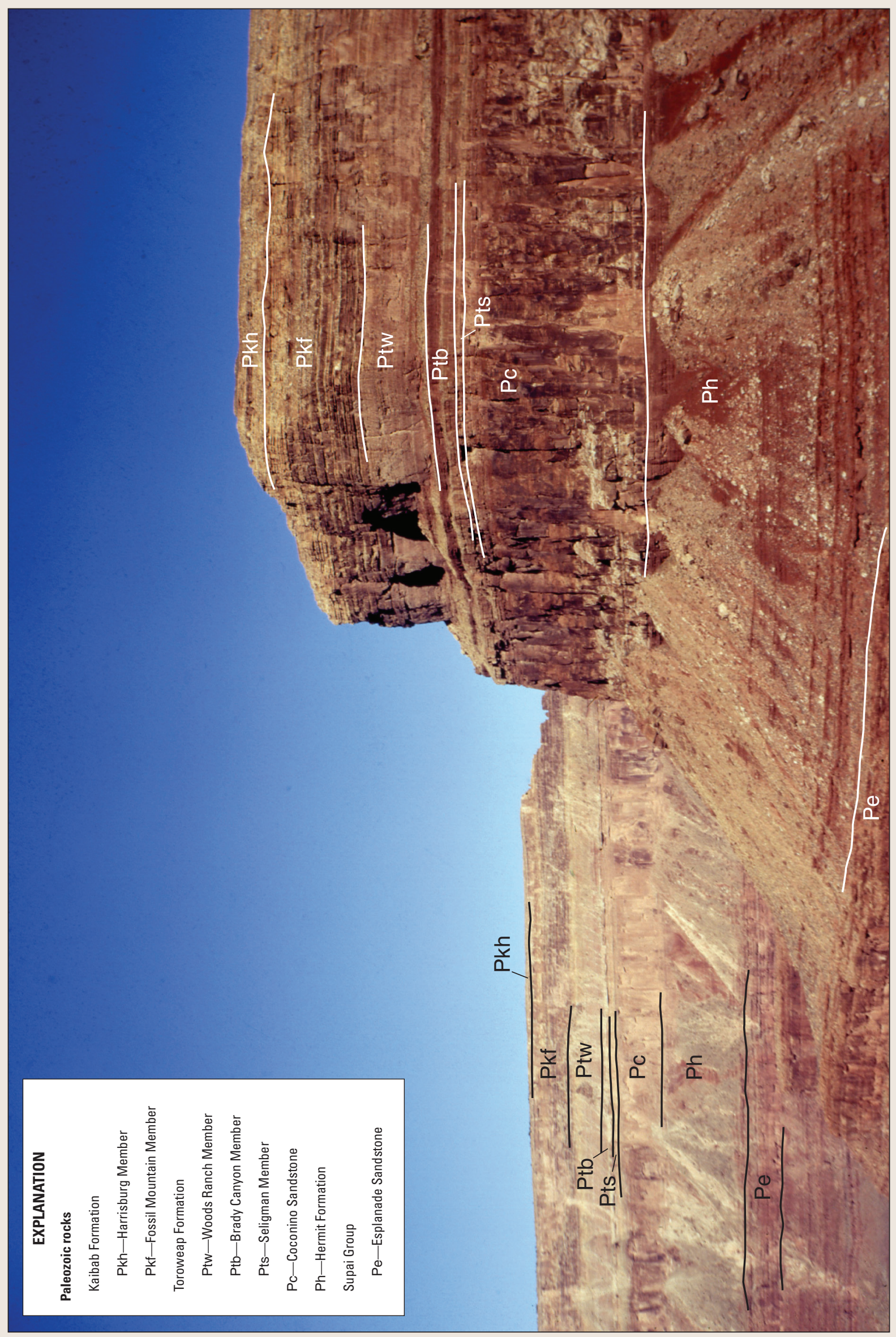

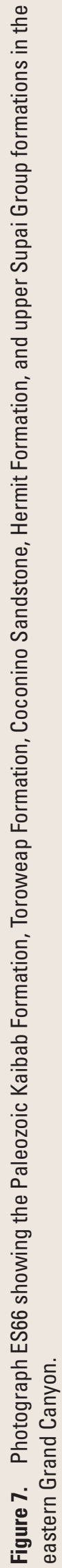




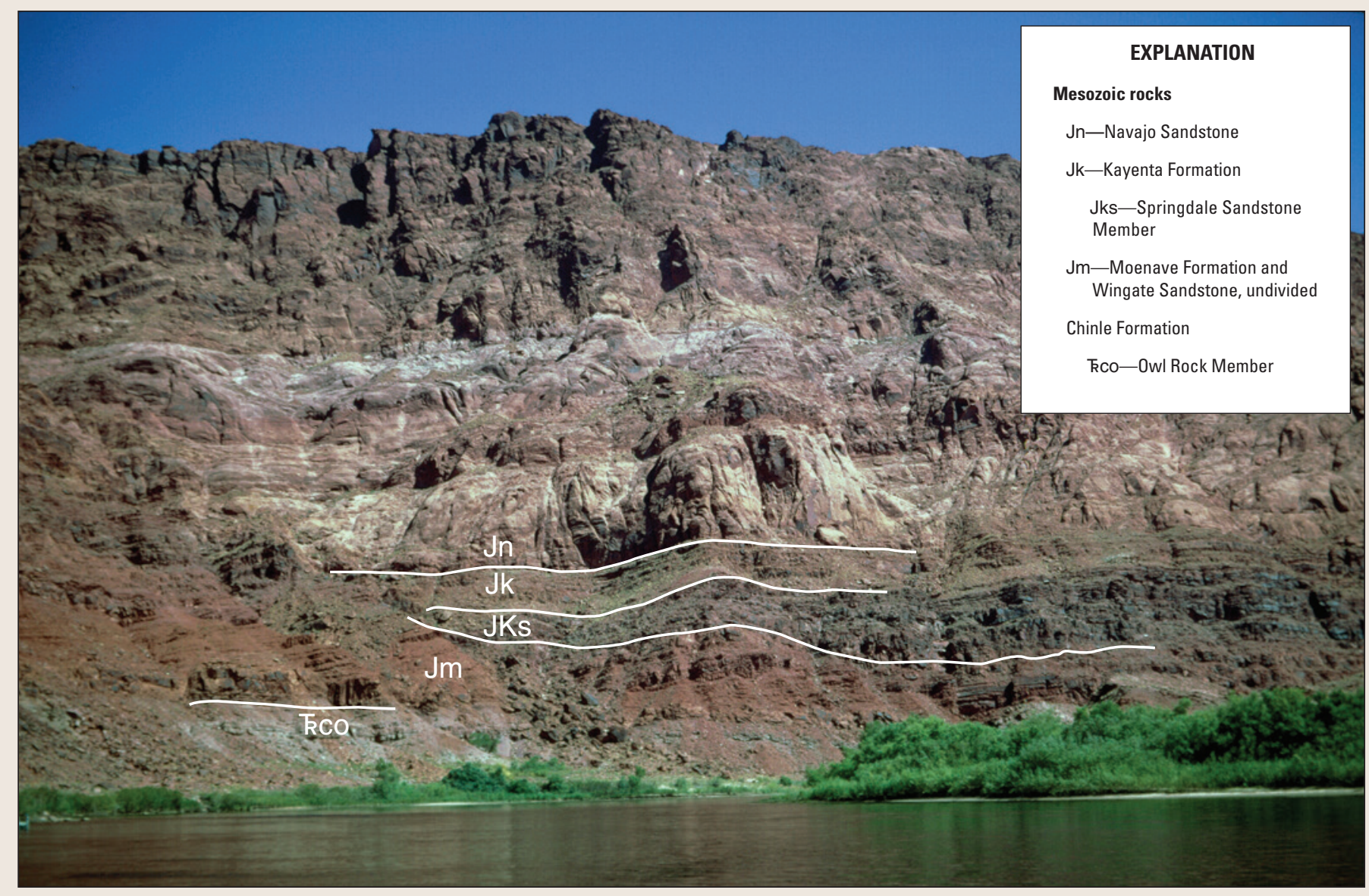

Figure 8. Photograph ES05 showing Mesozoic rocks in the eastern Grand Canyon.

\section{Acknowledgments}

Thank you to Center Director Colin Williams and Deputy Center Director Thomas Frost of the Geology, Minerals, Energy, and Geophysics Science Center for their enthusiastic support in publishing this unique dataset. The authors thank Stephen Box and Pamela Cossette for painstakingly reviewing the captions and coordinates for each photograph.

\section{References Cited}

Billingsley, G.H., Block, D.L., and Dyer, H.C., 2006a, Geologic map of the Peach Springs $30^{\prime} \times 60^{\prime}$ quadrangle, Mohave and Coconino Counties, northwestern Arizona: U.S. Geological Survey Scientific Investigations Map 2900, scale 1:100,000, https://pubs.usgs.gov/sim/2006/2900.

Billingsley, G.H., Felger, T.J., and Priest, S.S., 2006b, Geologic map of the Valle $30^{\prime} \times 60^{\prime}$ quadrangle, Coconino County, northern Arizona: U.S. Geological Survey Scientific Investigations Map 2895, scale 1:100,000, https://pubs.usgs. gov/sim/2006/2895/.
Billingsley, G.H., Hamblin, K.W., Wellmeyer, J.L., and Dudash, S.L., 2001, Geologic map of part of the Uinkaret Volcanic Field, Mohave County, northwestern Arizona: U.S. Geological Survey Miscellaneous Field Studies Map MF-2368, scale 1:31,680, https://pubs.usgs.gov/mf/2001/2368/.

Billingsley, G.H., and Hampton, H.M., 1999, Physiographic rim of the Grand Canyon, Arizona; A digital database: U.S. Geological Survey Open-File Report 99-30, 10 p., https://pubs.usgs.gov/of/1999/0030/.

Billingsley, G.H., Goodwin, G., Nagorsen, S.E., Erdman, M.E., and Sherba, J.T., 2019, Geologic and related photographs of the Grand Canyon region (1967-2010): U.S. Geological Survey data release, https://doi.org/10.5066/ F7WS8SHW.

Billingsley, G.H., Priest, S.S., and Felger, T.J., 2007, Geologic map of the Cameron $30^{\prime} \times 60^{\prime}$ quadrangle, Coconino County, northern Arizona: U.S. Geological Survey Scientific Investigations Map 2977, scale 1:100,000, https://pubs.usgs.gov/sim/2007/2977/.

Billingsley, G.H., Spamer, E.E., and Menkes, D., 1997, Quest for the pillar of gold, the mines and miners of the Grand Canyon: Grand Canyon, Ariz., Grand Canyon Association Monograph no. 10, $112 \mathrm{p}$. 
U.S. Geological Survey, 2002, Colorado River Mile System [Spatial database, BASE.RiverMileTenths] 1st rev. ed.: Grand Canyon Monitoring and Research Center, Flagstaff, Ariz., accessed January 25, 2015, at http://www.gcmrc.gov/ geospatial/data/.

Wenrich, K.J., Billingsley, G.H., and Blackerby, B.A., 1995, Spatial migration and compositional changes of MioceneQuaternary magmatism in the western Grand Canyon: Journal of Geophysical Research, v. 100, no. B7, p. 10,417-10,440.

\section{Geologic Maps of the Grand Canyon}

Billingsley, G.H., Block, D.L., and Dyer, H.C., 2006a, Geologic map of the Peach Springs $30^{\prime} \times 60^{\prime}$ quadrangle, Mohave and Coconino Counties, northwestern Arizona: U.S. Geological Survey Scientific Investigations Map 2900, scale 1:100,000, https://pubs.usgs.gov/sim/2006/2900.

Billingsley, G.H., Felger, T.J., and Priest, S.S., 2006b, Geologic map of the Valle $30^{\prime} \times 60^{\prime}$ quadrangle, Coconino County, northern Arizona: U.S. Geological Survey Scientific Investigations Map 2895, scale 1:100,000, https://pubs.usgs.gov/sim/2006/2895/.

Billingsley, G.H., and Hampton, H.M., 2000, Geologic map of the Grand Canyon $30^{\prime} \times 60^{\prime}$ quadrangle, Coconino and Mohave Counties, northwestern Arizona: U.S. Geological Survey Geologic Investigations Series Map I-2688, 1 sheet, scale 1:100,000, pamphlet 15 p., http://pubs.usgs.gov/ imap/i-2688.
Billingsley, G.H., and Priest, S.S., 2013, Geologic map of the Glen Canyon Dam 30' × 60' quadrangle, Coconino County, northern Arizona: U.S. Geological Survey Scientific Investigations Map 3268, 3 sheets, scale 1:50,000, pamphlet 43 p., https://pubs.usgs.gov/sim/3268.

Billingsley, G.H., Priest, S.S., and Felger, T.J., 2007, Geologic map of the Cameron 30' $\times 60^{\prime}$ quadrangle, Coconino County, northern Arizona: U.S. Geological Survey Scientific Investigations Map 2977, scale 1:100,000, https://pubs.usgs. gov/sim/2007/2977/.

Billingsley, G.H., Priest, S.S., and Felger, T.J., 2008, Geologic map of the Fredonia $30^{\prime} \times 60^{\prime}$ quadrangle, Mohave and Coconino Counties, northwestern Arizona: U.S. Geological Survey Scientific Investigations Map 3035, 1 sheet, scale 1:100,000, pamphlet 23 p. https://pubs.usgs.gov/sim/3035.

Billingsley, G.H., Stoffer, P.W., and Priest, S.S., 2013, Geologic map of the Tuba City $30^{\prime} \times 60^{\prime}$ quadrangle, Coconino County, northern Arizona: U.S. Geological Survey Scientific Investigations Map 3227, 3 sheets, scale 1:50,000, pamphlet $31 \mathrm{p}$., https://pubs.usgs.gov/sim/3227.

Billingsley, G.H., and Wellmeyer, J.L., 2003, Geologic map of the Mount Trumbull 30' $\times 60^{\prime}$ quadrangle, Mohave and Coconino Counties, northwestern Arizona, version 1.2: U.S. Geological Survey Geologic Investigations Series I-2766, scale 1:100,000, https://pubs.usgs.gov/imap/i2766/.

Billingsley, G.H., and Workman, J.B., 2000, Geologic map of the Littlefield $30^{\prime} \times 60^{\prime}$ quadrangle, Mohave County, northwestern Arizona: U.S. Geological Survey Geologic Investigations Series Map I-2628, scale 1:100,000, https:/pubs.usgs.gov/imap/i2628/.

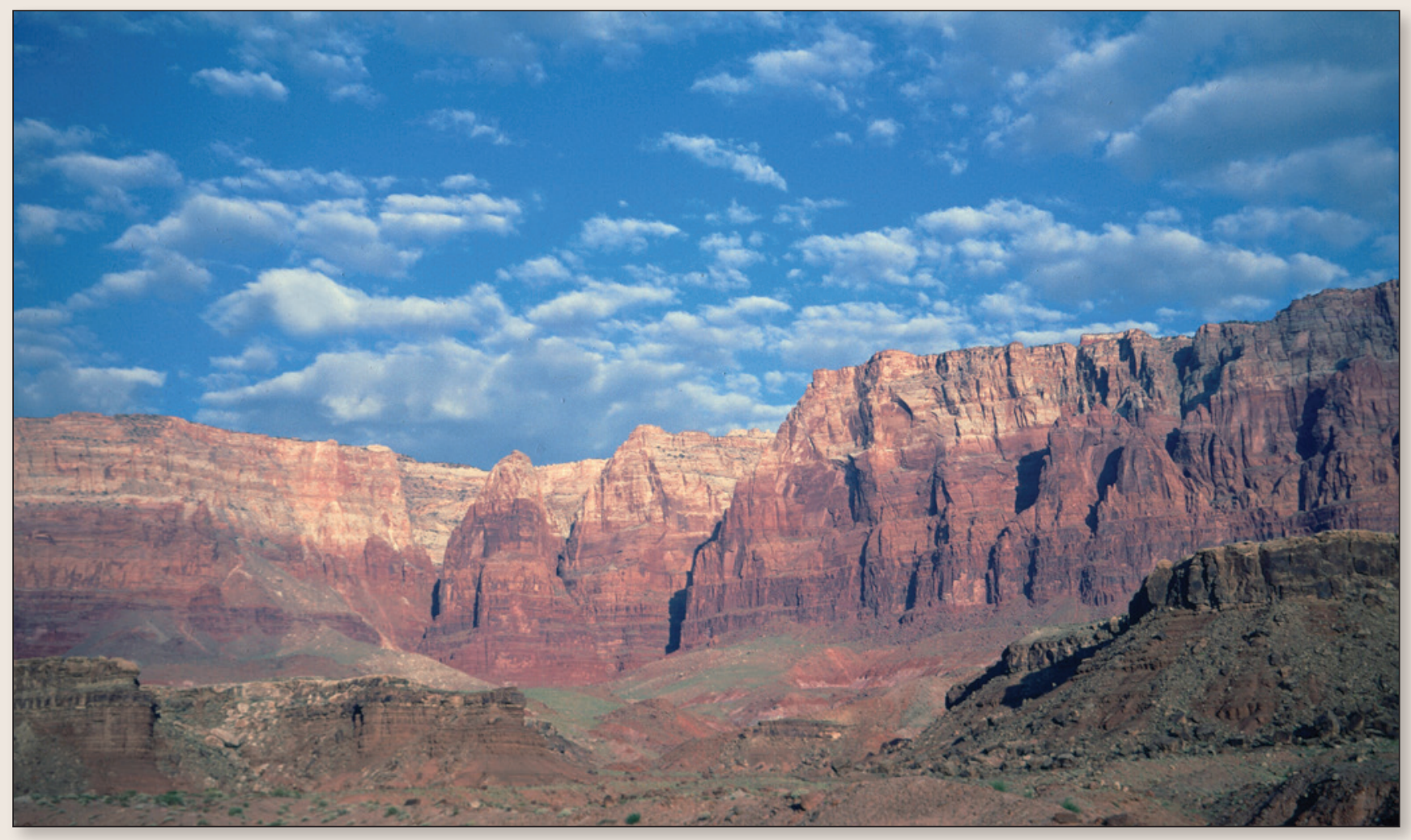




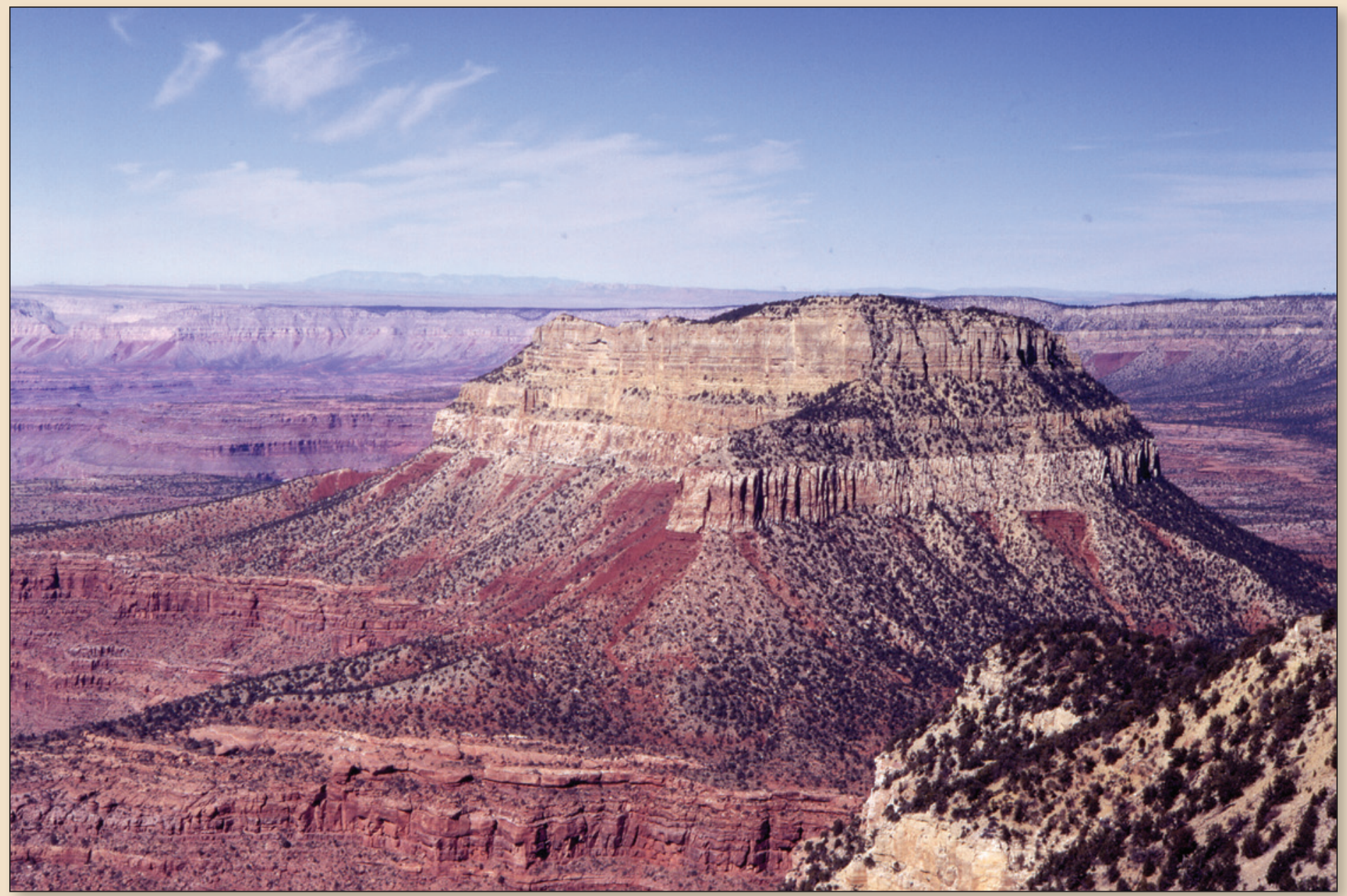

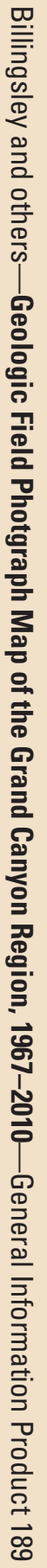
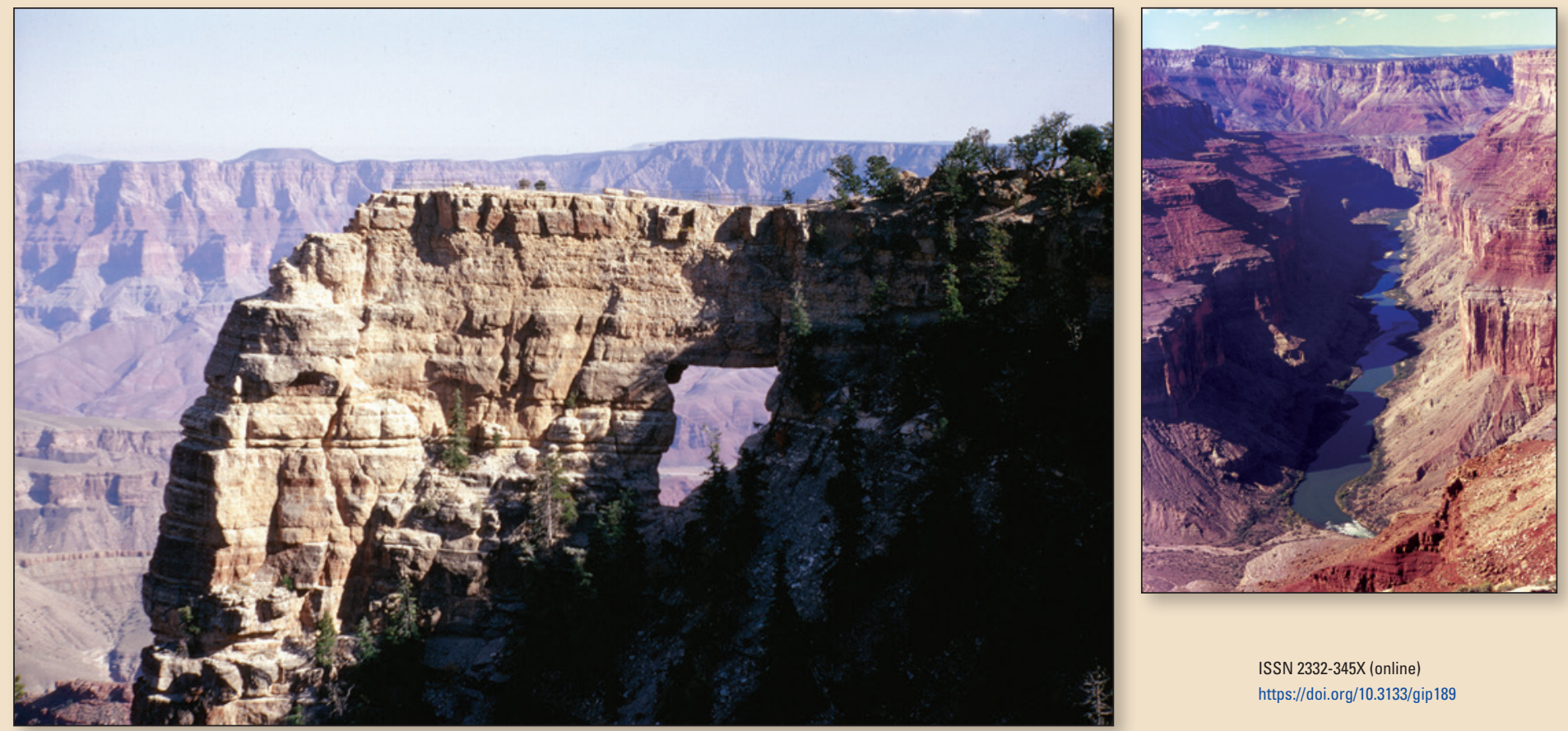

ISSN 2332-345X (online) 